\title{
Theoretical Development of the Individualised Individual Theory: A Qualitative Study of Cultural Practices in Nigeria and Women Students in Higher Education
}

\section{Dr. Onoriode Collins Potokri}

\author{
University of South Africa (Unisa), \\ Dept. of Educational Leadership and Management \\ potokc@unisa.ac.za or cnuvie@gmail.com \\ Prof. Venitha Pillay \\ University of Pretoria, \\ Department of Education Management and Policy Studies. venitha.pillay@up.ac.za
}

\section{Doi:10.5901/mjss.2013.v4n13p735}

\begin{abstract}
The main purpose of this study was to advance or extend Beck's individualized individual theory using cultural practices and women in Nigerian higher education as an x-ray. This study provided an elaborate introduction and background to cultural practices in Nigeria. Secondly, identified and discussed the main types or forms of cultural practices. Thirdly, identified the most dominant and pervasive cultural practices on the academic performance of married women students in Nigerian higher education. Qualitative research methodology - narrative enquiry was used. The study's population was drawn from two higher education institutions. Focus group discussion was used to gather data. Data was analyzed by means of reported stories of research participants. The findings include the inadequacy of Beck's individualised individual theory for understanding the experience of women amongst others.
\end{abstract}

Key words: gender, higher education, culture, individualised individual theory

\subsection{Introduction}

It is widely acknowledged that culture has multiple meanings. We draw on the ideas of Ortner (1974) and Beckman and Prinsloo (2007) to develop a workable understanding of culture. Ortner (1974: 72), defines culture as "the notion of human consciousness ... the products of human consciousness (i.e., systems of thought and technology), by means of which humanity attempts to assert control over nature. Beckmann and Prinsloo (2007: 240) define culture as the totality of socially transmitted behaviour patterns, arts, beliefs, institutions, and all other products of human works and thought characteristic of a community or population which provides them with a general design for living and patterns for interpreting reality. Beckmann and Prinsloo (2007) show that culture include behaviours, ideas, attitudes, values, habits, beliefs, customs, language, rituals, ceremonies, and practices peculiar to a particular group of people. Culture can ordinarily be defined as a way of doing things. Every culture has a world view that it uses to order and evaluate its own experiences. For Nigerians, this view originates in the indigenous ideas of classical West African history, supported and sustained by monarch institutions. In this study, we are concerned with the day to day cultural practices in the name of beliefs, norms and taboos enveloped in traditions and how it influence the experience of women in higher education particularly their academic performance.

Scholastically, cultural practice has been defined in different ways and by different authors, scholars and publishers. Among these definitions is that of Fadeyi (1995) and Mbiti (1969). According to Fadeyi, cultural practice is the application to life the totality of what is learned in the form of modes of thinking, acting and feeling by individuals as members of society. In the broadest sense, this term can apply to any culture at any time. Mbiti regard cultural practices as the traditional practices developed within specific norms or beliefs and Protected in many jurisdictions for indigenous people. In this study, Mbiti's definition is upheld because of its broadness and in our view, the definition encompasses all the major concepts and scope of cultural practices. Hence, it serves as the working definition used in this paper. Glele and UNESCO wrote that it is extremely difficult if not impossible to separate people from culture given their history. The traditions and cultural practices in Nigeria like in most part of the world represent the pinnacle of human activities, career and achievement (Dryden, 1999) and that cultural practices as norms, taboos etc (traditions), are responsible for the 
"making and unmaking" of personhood (Brettell \& Sargent, 2005; Lamb, 2005). In relation to women, Okeke (2001; 2002) argues that the future and destiny of women rest greatly on the traditions of the land. Traditional attitudes dictate that women are physical property of their husbands and deprive them of any authority over marital issues and relations (Chizea, 1993). It can be argued that womanhood lies at the mercy of various cultural practices. There is common belief that through cultural practices men are able to control the thinking of women because women have not been able to realize who they are, hence have failed to define themselves for themselves against the hurdle of culture (Collins, 1991).

\subsection{Research questions}

The research questions this study seeks to understand is as follows:

a. How can the experience of women students in higher education in Nigeria be understood?

b. How can the individualized individual theory that informs this study be extended?

\subsection{Reviewing related literature:}

\subsection{Cultural practices in Nigeria}

In Nigeria, cultural practices vary from one ethnic group to another. This largely depends on the tradition of the people and perhaps a blend, dilute and extract from their religion. Nigeria is a country where apparently different religion is practice, with Christianity, Islam and traditional worshipping well established. These religions are scattered across the country, with Islam dominating in the North, Christianity dominating in the South and traditional worshipping cutting across the country. It is important to note that some religious beliefs are imbedded in the culture of the people thereby reflecting in the aggregate or exact cultural practices in different part of the country. There appear to be some similarities in cultural practice across ethnic groups in Nigeria (Falola, 2001). Nevertheless, culture in Nigeria requires men and women to play different roles, so do young and older members. To be precise, and very often; different families, clans or lineages have their own specialized stories, songs, dances, crafts design and history put together to form their culture. It is therefore true according to Glele (1991); and Collins (1991) that culture create division of labour for different age, sex, marital status etc. With this, it becomes visible to see members of the community or society sharing a set of beliefs, values, habits and practices. These cultural practices jeopardize women liberation, empowerment, equality and emancipation (Giddens, 1991; Bolarin, 2005; Becks, 1999; 2002). This on the contrary, makes it absolutely difficult to accomplish the non - negotiable aim of higher education for women: to discover absolutely the life of the mind, to purse truth and to take a place in the world i.e. making women new, enlarging their world beyond the home and giving them a new identity (Collins, 1991; Becks, 2002). In Nigeria, there are numerous cultural practices. Cultural practices associated with women are usually liked to marriage. These include: Early childhood marriage, Female genital mutilation, Purdah, Son Preference, 40 days stay at home for post-natal women, Widowhood practice, Wife inheritance practice, and Wife beating etc. Given the linkage of these types of cultural practices to marriage, marriage as a cultural practice is briefly discussed below.

\subsection{Marriage in Nigeria}

Marriage itself can be regarded as a major cultural practice in Nigeria. Like in Ghana, marriage in Nigeria is seen as requisite stage in life, rather than an option, and remains the most important social institution and a major cultural practice (Salm \& Falola, 2002: 133). Cultural practices in Nigeria mandate marriage for men and women. It is only when people are married that they can be said to be 'responsible' in the society. Define broadly, marriage is a socially approved matting relationship that is expected to be stable and enduring (Benokraitis, 2005). Marriage is a critical rite of passage for both men and women, but the effect of this rite on the two sexes is very different (Watson, 2005). Marriage forms vary across many different groups in Nigeria because the members of a society construct its norms, or culturally defined rules for behavior. Norms that defined marriage include formal laws, traditional and religious doctrines. According to Bierstedt (1957), norms refer to ways of "doing" as opposed to ways of "thinking". Marriage in Nigeria is therefore synonymous with the existence of norms, although one is seldom aware of them until they are violated or until an attempt is made to enter a new environment where one is trying to establish oneself. Culturally, marriage in Nigeria takes place only when dowry is paid. In other words, 'there is no marriage without the payment of dowry'. It is therefore the start point and a compulsory requirement for marriage. Dowry is a socially-legitimised payment normally given by the groom's family to the bride's 
family. Our experience together with the existing literature aids reasonable understanding of marriage as a cultural practice in Nigeria. Nevertheless, we acknowledge that as a male Nigerian and a South African woman, we may not have intimate knowledge of marriage and cultural practices women experience in Nigeria. It is feasible that the data generated in this study helped to reveal cultural practices not accounted for in the reviewed literature.

\subsection{Theoretical framework}

Ulrich Beck's (1992) individualised individual theory was used to interpret the data. Beck, (1992; 2002) argues that social actors, such as culture, tradition, necessitate changes in the attitude, behaviour and perception of women towards marriage, education and general life style. Falola (2001) believes that change is an attitude, and that the behaviour of individuals is a fallout of culture. Culture is embedded in society; people live and are part of society, and culture and society are inseparable. For this reason, it is almost impossible for people to take themselves out a culture - no wonder sociologists say it is a way of life. The individualised individual theory is concerned with self - fulfilment and achievement of people as individuals through liberation and empowerment. In this study our focus was on women students in higher education therefore we relate the theory to women. Similarly, in Beck's theory of individualised individual, Beck related the theory to both men and women but he emphasised its application on women who are particularly interested in creating identity for themselves. According to Ulrich Beck the most dominant and widespread desire in Western societies today is the desire to live a "life of one's own". More people aspire to actively create an individual identity - to be the author of their own life. The ethic of individual self-fulfilment and achievement can be seen as the "most powerful current in modern societies" (Beck, 2000: 164). But what drives people - may they come from Europe, America, South America, Asia, Africa or Australia, - to increasingly take control of their lives? It is not the rise of a new era of egoism as media debates over the 'Me first-society' suggest (Schoetere, 2002). The concept of individualisation according to Schoetere does not mean unconnectedness, isolation, loneliness or the end of all kinds of society. As Beck puts it, it rather means the exchange of industrial and traditional society ways of life by new ones, in which individuals must 'produce' their biographies themselves.

A key contributory factor to the development of the individualised individual theory is the liberation of women. As Becks (1992:105) states, in reflexive modernity, "people... are removed from the constraints of gender". His argument points to the idea that men and women are being released from their traditional, ascribed gender roles. Concurrently, Beck points out that these changes reside more in the minds than in their actual practices. His strong advocacy for women's liberation is linked to feminist exploration and explanations of structures of power and gender, particularly in second-wave feminism (see Skelton, 2005). Women's liberation, according to Beck (2002:202; Beck \& Beck-Gernsheim, 2002) is identified as the release from 'compulsory housework and support by a husband'. This we believe is good for women as it will motivate and encourage them in their education. Although Beck writes that power brings about liberation, he fails to provide a concrete, clear and precise definition of what he meant by power and how it informs his theory. In our understanding, and aligning to Skelton's (2002) opinion, Beck sees power as a limited resource with the implication that men, through masculinism, are able to access it and that this is enabling for them but disabling for women.

We consider Beck's theory of the 'individualised individual' for the study because of the increasing attention it is receiving from social scientists, especially those interested in social justice, women's education and equality issues (Skelton, 2005). Secondly, Beck's argument has some commonalities with Buchmann (1989) and Giddens (1991), who reveal that societies have moved away from the old 'left versus right' political distinction (societies where people are born, live and die within a confined boundary with the same way of life as their parents) and are being replaced by globalisation and globalised citizenship.

\subsection{Methodology}

A qualitative empirical investigation was used in this study. In line with this, a narrative approach was specifically employed. This is an approach where research participants narrate their stories. Narrating is a fundamental and universal way for people to organise their understanding of the world (Cortazzi, 2002: 384). And construct themselves through selfreflexivity (Becks, 1992; 2002). Self-reflexivity is usually in form of storytelling. Telling stories is a key way of making sense of experience (Brunner, 1990).

The study was delimited to two higher education institutions in Nigeria: A University and a College of Education in Lagos State, Nigeria. Participants ranged from $18-45$ in age and were undergraduates in their third year of study. Only students of the faculty/school of education were selected for the study. A total of 12 women students were randomly 
selected and served as participants (6 from each institution). In each institution: 3 participants are married women and 3 were single women.

Data was collected through two focus group discussions one at each institution. The first researcher (xxx) conducted the focus group discussions. We chose to have another woman not involved in the research to be present at the discussion as the researcher was a male and the participants may have felt uncomfortable in his presence. The 'independent woman' was there primarily to give the participants a sense of comfort, to function as a chaperone as it were, and did not participate in the discussion.

The questions used to guide the focus group discussion were:

(1) Why did you choose to study in higher education institution? (2) What support do you get from your parents (if any)? (3) What support do you get from your husband (if any)? (4) What are the challenges you face in your studies? (5) Can it be true or false that cultural practices affect the academic performance of women students in higher education? (6) How do cultural practices affect the academic performance of women students in higher education? (7) Which category of women students (single or married) in higher education do cultural practices affect most? (8) Which cultural practice affects you most as a woman student in higher education? (9) Between married women students and single women students in higher education, which do you, think perform better academically? Give reason(s) for your answer or opinion. (10) As a woman student studying in higher education institution, are you satisfied with your present academic performance?

\subsection{Data presentation and analysis}

The data remained at the level of words and statements. These words or statements are those of the research participants and, at some point, the researchers used some words or statements of theirs as a means of interpreting what the research participants have said. Such words or statements are used where necessary to further clarify the opinions of the research participants. The words or statements in italics are direct quotes of participants. The names of participants are also in italics. Importantly, the names of participants are pseudonyms.

\subsection{Unfolding the conversation at the College of Education}

As we commenced the discussion, one of the participants, Ronke said "I am very happy to be here, at least I now have the opportunity to speak to someone outside my friends about the problems and challenges I face studying at higher education institution". Most of them were of the same opinion. For many of them, discussing their experiences was fun, relieved them of emotional pain and constituted an avenue for other women students to learn from their experiences.

When the discussion started formally, the researcher was amazed to hear a participant, Lola, a married woman student say that her primary reason for pursing higher education is because of her husband. She said my husband always shut me up whenever we are discussing or having a debate at home; he believes I have nothing to contribute simply because I am not a graduate like him, she said. In her words "Within me, it hurts especially when he says it in the presence of our children". She said further, "I have a business that is doing very well and I support the family financial yet he abuses me because he is an NCE (national certificate of education) graduate". In anger, she said "I even make more money than him. This was provoking and I can no longer take it because our children are growing up and I do not want them to see me as an illiterate as their father have always painted me." Another married women student, Funmilayo, stated that her reasons for choosing to study in higher education institution include "a taste for knowledge; influencing my children; empowering myself so as to be able to contribute to the country's development". The third of the married woman students, Ejiro, highlighted that "being a graduate of higher education will help me become a better mother and wife that other women in the neighbourhood will want to emulate".

With respect to the support that women students get from their husbands, only one woman student acknowledged that the husband was supportive. Her name is Ejiro. According to her, "my husband supports me financially, and in many other forms". She concludes that her husband's support is total.

For the other two married women student - Lola and Funmilayo - their husbands are not supportive. Lola said, "my husband is against my schooling; he complains all the time that I have neglected him and the children". The other married woman student -Funmilayo - complains that she "finances her schooling from the little salary she earns as a teacher in a private nursery school". Importantly, none of the married women students in this discussion ever spoke about support from their parents. When the researcher asked, they said differently but in agreement that their parents do not support them financially in their schooling. 
Despite the differences in the support they received from their husbands, they were all not happy with their academic performance.

As the researcher struggled with his emotion, one of the married woman participants, Funmilayo revealed that her biggest problem is her husband's second wife. According to her, the husband is a polygamist - married to two wives and cannot afford to finance or support her schooling without doing same for the other woman. However, the other woman would not even support the idea.

There were three single women participants (Ronke, Amaka and Slyvia) and they revealed that they get support from their parents. With regards to the question of why they chose to study at a higher education institution, Ronke and Slyvia said that they love teaching and wants to become teachers and they can only become qualified teachers if they obtain a national certificate of education. The third single woman participant, Amaka said that her reason for choosing to study in higher education is to empower herself, and to contribute to nation building.

In response to the question of which category of women does better academically and which category is affected most by cultural practices, all the participants said that single women perform better academically and that married women students are affected most by cultural practices. Except for one (Ronke), she said "my parents are poor and cannot afford to support me financially the way I should be supported but they are trying in their little capacity". She believes that she could do better academically if she had more support.

At one point the discussion became very exciting. One of the single woman participants, Amaka attempted to hijack the discussion. She wanted to do all the talking and was not giving others the opportunity to talk; however, the researcher was quick to notice this and he cautioned her by telling her to allow others to talk. Nevertheless, she was very instrumental as she voiced some previously unvoiced and vital issues. She said that she came from a polygamous home where there is academic competition between all her father's children so she had no choice other than to do well at school because the father would only give them (children) the money needed for school once. Therefore, no one can afford to fail or not to do well because anyone who failed or did not do well would have to leave school.

As the discussion progressed, the researcher allowed the participants to do more of the talking with him coming in at intervals to ask questions. At this juncture it was evident that the participants were more comfortable speaking to him than writing.

Here, other views voiced by the participants are included below:

- $\quad$ Two single respondents (Sylvia and Amaka) said that as long as they have chosen to engage in higher education they will not marry because they cannot see themselves combining education and marriage. For them the cultural practices affiliated to marriage are something they cannot live with whilst studying.

- $\quad$ One among the single participants Ronke said that she would like to get married before she proceeds to her higher degree programme at university. She argued that a husband is a woman's umbrella and crown; a woman commands respect when she is married. Furthermore, if a woman reads too much, men will not want to ask for her hand in marriage. Both Sylvia and Amaka agreed that a woman commands respect when she is married. They added that a woman in Nigeria is tag (regard) responsible only when she is married. Even though they agreed on this, they insisted that they would only get married when they had completed their studies, because of the task of combining marriage and schooling.

- $\quad$ One married woman participant, Lola said that her academic performance was discouraging. If she had known the difficulty of combining marriage with schooling, she would not have got married.

- $\quad$ Another married woman, Funmilayo, said that one major problem they face is the lecturers. The lecturers seem not to understand married students' problems. "They do not encourage us. They shout at us like babies and treat us like kids. Some lecturers use our weakness of not been able to do or submit assignments on time to ask money from us believing that our husbands have got the money to give us."

\subsubsection{Conversation at the Lagos State University}

The participants spoke one after the other when the conversation started.

First to speak was a married woman student who specifically requested me to address her as "mummy Bola". Bola is her daughter's name, and according to her, she is good at explaining herself in speech rather than writing. She realised that she was going to take much time because no one had spoken so she pleaded with others to kindly allow her narrate a short story about herself. In a more personal voice she concluded:

... My husband does not support me in any way. In fact he does not care about my progress at school all he knows is that his wife is a student of a university. Even at this, my husband's family 
still gives me problems thinking that it is their son (my husband) that is paying my fees. Thank God for my little business that allows me time for studies and provides me money for my fees.

At the end, with smile she said: "I am very happy with my academic performance." At that point she revealed that her present cumulative grade point is above 3.50. She ascribed her good performance to hard work, determination and knowing what she wants in life as an adult. For another participant (Zainbe - married woman) considers herself lucky to have a caring, loving and supportive husband. Having heard the story of "mummy Bola", she said that she works as a teacher but her husband would never allow her to pay fees and buy books from her salary. Her husband pays. She says that her husband helps with domestic work at times and frequently comes to the campus to pick her up after lectures. She did complain, however, about the demands of her husband's family to attend extended family gatherings and social events. This is not helpful as most of these events clash with lectures. She said that her academic performance is satisfactory but her husband believes that she can improve.

Third to speak was Evelyn, a single woman student. In her words, "I am thirty five years of age, not married. If there is anything I really want in life now is to be married, have my own children and a home that I can call my own. Yes, it is good for a woman to have higher education but it should not take the place of marriage she said. In fact higher education should come after marriage." She further said that she envies participants and other course mates of hers who are married. For her, schooling is like going through hell. No one motivates her. It would have been better to have a husband who does not support her, but at least looking at him and the children would be inspirational for performance and help develop interest in studies. At this juncture the researcher asked her about the motivation and support she gets from her parents and family since she is not married. She responded with anger and said "I do not get any support from my parents and family. They believe and often say to me what do I want higher qualification for without a husband." According to her, "the only support I get from them is preaching on marriage. The husband they clamour for is not forthcoming; should I kill myself?" The researcher's last question for her was: Are you happy studying and how are you performing academically? Her response was "no". According to her, she is in higher education institution simply because of the qualification to gain promotion at her place of work. For academic performance, she is not performing to her satisfaction but what can she do, she says.

Next to speak was lyang, a married woman student. She had mixed feelings about her husband. She wonders if her husband feels for her. "All the time he (my husband) wants me to do one thing or the other for him even when it is not convenient for me; most annoying is when he comes back home late at night he still wants me to wake up to get his food for him The only time my husband does not request of me to do anything for him or disturb me is when I am studying or doing assignments. Most times I pretend to be studying especially when I am very weak or tired to do any domestic work. [Importantly] my husband pays my fees and provides all my educational needs. [To add to this] my parents, family and husband family has been very supportive. With regards to her academic performance, she said that she is very happy and her husband is equally impressed. She acknowledged the occasional inspiration she gets from the noise her little children make around her when she studies at home.

After lyang's narration, two participants were left to speak. These participants are both single women, Efe and Jumoke. In her low and soft spoken voice Efe said "I have learnt a lot here today. This conversation has helped to change my thinking about marriage." Marriage and cultural practices are almost universal, and require patience and determination on the part of women to be successful generally as indicated in the story of some of the married women participants. Nevertheless, Efe thinks it is ideal for every woman to be married. She added that higher education would help women become better managers of their homes when married. And for single women, it will help to prepare them for future challenges. Remarkably, she revealed that her primary reason for choosing to study at a higher education institution was to have a profession, develop a career and have a significant impact on her family especially her children when she gets married in the near future. She believes she is privileged to be the first daughter of a mother and father who are both averagely rich. The only problem she has with her father is his recent marriage to another woman because the mother gave birth to three of them who are all girls and her father now wants a male child. "Even at this, my father still gives me and my sisters all the support we need for our studies" In terms of academic performance, Efe said that she is very satisfied with her present performance.

By this time the discussion/conversation had already taken more than the time I (the researcher) had envisaged. It appears that some of them really wanted to leave for home. When the researcher noticed of this he requested them to give him additional time so that the last participant (Jumoke) could speak, they agreed but Jumoke was quick to say "I do not have anything new to say expect for my worries on my academic performance, my academic performance is very poor and dissatisfactory". She further revealed that she is currently on a cumulative grade point of less than 1.50. 


\subsection{Discussions and reflections on focus group conversation}

In the course of narrating their stories, the women revealed their experiences in higher education. They stress on the dominant cultural practices that affect their academic performance the most. In their stories, they see these dominant cultural practices as educational challenges which in turn affect their academic performance in one way or the other. These challenges are regarded as critical determining factors for academic performance of women students in higher education. The challenges as revealed are financial problem, cultural practices and psychological problems. Among these challenges, some participants both married and single spoke intensively on the practice of polygamy as one of the dominant cultural practices that affect the academic performance of women students in higher education. In their story, participants showed how women want marriage. Although they narrated that marriage with regards to marital responsibilities influences their academic performance yet they said that it is ideal and compulsory for women to be married. Participants cherish marriage to the extent that single women participants envy their colleagues who are married. To this end, some single participants highlight that they will not pursue or enroll for higher qualifications degree in higher education except when they get married. While, single women participants spoke on the need to be compulsorily married, married women participants spoke mentioning their husbands, children and home frequently.

The stories of the sampled participants illustrate that their success or failure in a terms of academic performance depend largely on the support they get from their husbands and parents. Women student participants who get support from their husbands appear to be performing better than their counterparts who are equally married but do not get support from their husbands. The same situation applies to single women student participants who get support from their parents. This suggests that when women are married, the responsibility of providing educational needs or support is shifted from the parents to the husbands. One major hallmark of the sampled participants' stories was recognizing the importance of higher education irrespective their different reasons for enrolling for higher education and their challenges. The stories of the sampled participants both married and single pin point that financial support and psychological support are the two common supports they get.

\subsection{Extending Beck's individualised individual theory}

In this section we discuss the singular important theoretical development that this study signals: that the women in this study indicate that marriage is a social condition to which they aspire and that they do not see this aspiration and higher education as being mutually exclusive or incompatible. Participants in this study are clear that women desire marriage and are committed to sustaining their marriages.

In an attempt to extend the singular important theoretical underpinnings of this study, we link this important finding to Beck's theory of the individualised individual. According to Beck (1992), the individualised individual theory states that women's liberation is not only rewarding to people as individuals but also to societies, and depends largely on the empowerment of individuals. This theory further explains the interplay between social actors and the desires of women in a contemporary society. Participants in this study demonstrated this interplay in their stories when they linked their experiences and challenges in higher education to marriage and cultural practices especially as they relate to their husbands, children and home. Furthermore, Beck reveals that social actors necessitate changes in the attitude, behaviour, and perceptions of women towards marriage, education and general life style. Cultural practices, marriage to be precise, as a social actor necessitate changes in the attitude of participants towards higher education. Cultural practices are responsible, for participants believing that marriage is a top priority in their lives, as Efe, Ronke, Sylvia and Amaka agree that marriage is ideal for every woman and that a husband is the umbrella and crown of a woman. Also, cultural practices inculcate, in the minds of people and the public, that only when a woman is married can she be seen as a responsible woman. This belief has led some participants to see their academic performance as less important in comparison to their marriage.

In the individualised individual theory, Beck refers to empowerment and liberation together. His theory suggests that empowerment leads to liberation for an individual. Furthermore, Beck and Beck - Gernsheim (2002:202) identify women's liberation as the release from "compulsory housework and support by husband". In this study, participants agree with Beck's theory that women want higher education to empower themselves but it is not enough. For these participants, empowerment and liberation will not give them fulfilment. Fulfilment for them is the addition of marriage to the empowerment and liberation that Beck's individualised individual theory emphasises.

In an effort to extend Beck's theory of the individualised individual as being founded on empowerment and liberation, we would argue that the element of fulfilment as identified in this study would be an added dimension to this theory. In other words empowerment, liberation and fulfilment are all important to the aspirations of women. 
In this study, participants complained about cultural practices yet they did not advocate the eradication of such practices. This is contrary to the expectations of Beck's theory and recent studies conducted by Bolarin (2005). Bolarin (2005:161) advocates for the eradication of cultural practices affecting women's education when she states that women's enrolment and participation in higher education would improve greatly if the current traditional and cultural practices that prevent women from having equal access to education were to be phased out or reduced. Married women participants in this study cherish their marriage. Also, single women participants want to be married despite the responsibilities attached. This point is significant, especially when one compares it to the cardinal focus of Beck's individualised individual theory which pinpoints that women should be empowered and liberalised in order to attain fulfilment in life and enable them contribute to national development. In his theory, Beck posits that the empowerment and liberation of women will help to take women out of their homes and their confined roles. Yet for women in this study empowerment is not about liberation from the home and conventional chores, but to some extent the attainment of them.

Importantly, as a means of achieving empowerment and liberation for women, the individualised individual theory postulates education, particularly higher education for women, as a means of empowerment and a key to achieving liberation. Participants' views in this study concur with Beck's theory that the empowerment of women via higher education could possibly enable women to contribute to national development. All participants, both married and single, said that they need higher education. This suggests that they need something in addition to their homes, husbands and children.

\subsection{Conclusion and Recommendations}

We entered the research sites knowing that cultural practices is one among the numerous factors that influence the academic performance of women students in Nigerian higher education, but we did not expect the extent or level of significance to which it influences academic performance. Further, we expected participants to complain about cultural practices and possibly call for their eradication so as to help promote higher education for women. Our expectation with respect to the complaints was met, as almost all the participants complained in one form or another about the effects or influences cultural practices had on their academic performance. Despite their complaints, both the married and single participants in this study support cultural practices. They said that such practices make women truly responsible. In short, while Beck identifies empowerment and liberation as being central to women's aspirations, the women in this study suggest that fulfilment is also an important dimension of their aspirations. They identify marriage as part of this sense of fulfilment as it is both personal and culturally familiar. Participants in this study felt strongly that they wanted to be married. They argued that the sense of fulfilment that marriage gave them was important to them. While they desired liberation and empowerment through higher education, they also wanted personal and cultural fulfilment. We suggest that Beck's assertions regarding liberation and empowerment are important, but not enough. What this study suggests as well as recommend is that Beck's theory of the individualised individual be expanded to include elements of personal and cultural fulfilment. In short, liberation and empowerment without fulfilment are inadequate in terms of understanding the theory of the individualised individual.

\section{References}

Journals:

Beck, U. (1999). Theory of Reflexive Modernization: Problematic, Hypotheses and Research Programme. Theory, Culture \& Society, Vol.20, No. 2

Bolarin, T.A. (2005). Women participation in higher education in Nigeria: Values education; choices, and counter cultural traits. Nigerian Academy of Education, pp. 144-161.

Books:

Beck, U. (1992). Risk society: Towards a new modernity. London: Sage.

Beck, U. (2000). What is globalization? Cambridge, Polity.

Beck U. (2005). Power in the Global Age. Cambridge, Polity Press.

Beck U \& Beck-Gernsheim, E. (2002). Individualization: Institutionalized individualism and its social and political consequences. London: Sage.

Beckmann, J. \& Prinsloo, S. (2007). Growing human rights and values in education. Edited by J Nieuwenhuis. Pretoria: Van Schaik

Bierstedt, R. (1957). The Social Order, New York: McGraw Hill.

Brettel, C. B \& Sargent, C. F. (2005). Gender in Cross- Cultural Perspective. Fourth edition, Pearson Education, Inc. upper saddle River, New Jersey.

Collins, P. H. (1991). Black feminist thought. Routledge, London. 
Dryden, C. (1999). Being married, doing gender: A critical analysis of gender relationships in marriage. London: Routledge.

Falola, T. (1999). Yoruba Guru: Indigenous Production of knowledge in Africa. Trenton, N.J: AfricaWorld Press.

Falola, T. (2001). Culture and Customs of Africa: culture and customs of Nigeria. Greenwood Press. Westport, Connecticut: London.

Giddens, A. (1991). Modernity and self-identity: Self \& society in the late modern age. Cambridge: Polity.

Mbiti, J. S (1969). African Religions and Philosophy. London: Heineman.

Okeke, E.A.E. (2001). Women's education in Nigeria. Lagos: NERDC , 9-125.

Salm, S. J \& Falola, T. (2002). Culture and Customs of Africa: culture and customs of Ghana. Greenwood Press. Westport, Connecticut: London.

\section{Sections in edited books:}

Chizea, D.O. (1993). The Impact of Maternal Mortality on Women development. In O.F. Giwa-Osagie and Talib (Eds.) Maternal mortality: A way out. Lagos: Duff Resources and Conference Ltd.

Cortazzi, M. (2002). Developing a double vision: Analysing narratives and documents in educational research. In M. Colemen and A. Briggs (eds), Researching educational management and leadership. London: Paul Chapman.

Fadeyi, B. (1995). Aspects of Cultural Practices in Africa. In Fundamentals of General Studies: A publication of the General studies Division Lagos State University.

Gele, M. (1991). Culture in Africa: An Essay on Society and Culture, In Africa Today. Second edition, published by Africa Books Ltd, London.

Ortner, S. B. (1974). Is female to male as nature is to culture? In Women, Culture, and Society, ed. Michelle Z. Rosaldo and Louise Lamphere, Pp.67 - 88. Stanford: Stanford University Press.

\section{Thesis / Dissertation:}

Bhasin Veena 1981. Ecological Influence on the Socio cultural System of the Gaddis of Bharmour Sub-Tehsil, Chamba District, Himachal Pradesh. Ph. D. Thesis, Unpublished. Delhi: University of Delhi.

\section{Web source:}

Schroeter, J. (2002). The Ally McBeal in Us: The importance of role models in identity formation. www./F:/becktheorynew.htm. Assessed on the 27th January, 2011. 
